\title{
Between Fear and Survival: Human Security Issues in Citarum River Basin, Indonesia
}

\author{
Arry Bainus*, Wawan Budi Darmawan, Dina Yulianti and Luthfi Hamzah Husin \\ Padjadjaran University, Sumedang, Indonesia \\ Corresponding author: arrybainus@unpad.ac.id
}

Submitted: 2 April 2019 | In revised form: 5 November 2019 | Accepted: 22 December 2020 |

Published: 19 February 2021

\begin{abstract}
This article offers an empirical finding of human security issues in Citarum River, Indonesia, which was once labelled as the dirtiest and most polluted river in the world. Using a theoretical framework based on actor-based security model, this research seeks to analyse a local community's experience in a village affected by severe environmental degradation of its river basin and its relation to other actors in security policy making process. The article explores how a local people evaluate the ongoing environmental degradation and its impacts to their life. This analysis leads to the finding that local people are aware of the threats from their environment, but at the same time they still have to depend on the economic activities that has been polluting the river. This condition makes them unable to advocate for what they experienced to the policy makers and choose to be resilient. On the other hand, the government's policies tend to ignore the perspective of the local community in formulating a security policy. This supports previous studies that the concept of human security still has little impact on addressing environmental issues, especially at policy level.
\end{abstract}

Keywords: actor-based security model; Citarum River; environmental degradation; human security; security policy

\section{Introduction}

After the end of the Cold War, the focus of security studies shifted from military and inter-state studies to non-traditional threats with the potential to put people in danger. One of those is environmental degradation [1-3]. That threat is due in part to increased industrialisation and changes in land use, especially in developing countries [4-6]. One case which has caught the attention of the international media is the severe pollution of Citarum River in West Java, Indonesia. It came to public attention after several global mainstream media reports described it as 'Indonesia's Most Polluted River' [7] and the 'World's Most Polluted River'
[8]. Previously, the Telegraph (2014) [9] had published a story entitled 'Citarum, the most polluted river in the world?' Unreported World (2017) [10] also broadcast 'The World's Dirtiest River'.

A case study by Greenpeace Indonesia and Wahana Lingkungan Hidup or Walhi (Life Environment Commission) of West Java found high levels of heavy metals, such as hexavalent chrome (Cr6+), and dangerous organic chemical pollutants, such as Diethyl phthalate (DEP), from industrial waste [11]. The high content of faecal coliform and low dissolved oxygen concentration in the Citarum River also renders it incapable of meeting the minimum water quality standards [12]. According to the Indonesian Ministry of 
Health [13], such polluted water will affect people's health if consumed. This condition is mainly caused by severe waste discharge along the river basin, especially in the upper area, from agriculture, industry, domestic workers, and another business services [12,14,15].

From the perspective of human security, people who live in such perilous conditions are dealing with insecurity. As first formulated in the 1994 United Nations Development Project, Human Development Report (UNDP HDR), the concept of human security is comprised of two basic components: freedom from want and freedom from fear [16]. The Secretary-General's report of 2005 added a third pillar: the freedom to live in dignity [2]. This idea has changed the way security is understood, especially since the end of the Cold War, from a state-centred to a people-centred view which posits security at the individual level. The main concept of the human security is that people have the right to live in dignity, free from poverty and inequality [17]. In this light, the environmental degradation of Citarum River can be seen as a constant source of threat to the people living in its environs.

The policy in the basin has long involved the interventions of national government and so little by little.international communities. Strongly influenced by greenneoliberalism, in 2007 the Indonesian government borrowed money from the Asian Development Bank (ADB) to create a project called 'Integrated Citarum Water Resources Management,' often abbreviated as 'IWRM,' to manage the severe pollution [18]. This policy tried to integrate the disparate stakeholders to restore the water quality of the river by integrating rules and bureaucracy and involving public and non-governmental organisation (NGO) participation. The IWRM, however, did not work effectively in practice because of poor management between the agencies, incompetent human resources, and allegations of corrupt and inefficient government $[18,19]$. Seen in this light, previous policies only focused on security governance and often ignore the perspective of local communities who feel the negative impact directly from environmental polluting.

The poor management of Citarum River resources inevitably raises the risk to human security. As pointed out by [3], there are at least six threats that arise in degraded river environs: river ecosystem damage, food and clean water scarcity, energy shortage, social issues in the local societies and climate change. These environmental threats all occur in Citarum and, by way of contrast, government policies in overcoming these threats do not focus on dealing with human security issues that are actually faced by the local community around the river basin. These facts in the Citarum River support [2] argument that after 20 years, human security as a concept still carries minimal impact on addressing environmental issues, including on how governments make security policy.

In this study we use actor-based security model developed by [20], where the function of this model is to identify various actors relevant to how security is understood. The perspective of local community, who are vulnerable and threatened, hence, becomes important in making security policy. Seen in this light, the Indonesian government's policies in dealing with environmental threats in the Citarum River have not accommodated people's own subjective assessment of their safety. Some research questions arise from this problem which will be answered including: how does the local community perceive the threats and safety they have experienced so far?; why are they unable to articulate and advocate for their conditions to policy makers?; and how is the existing security policy viewed from the perspective of the actor-based security model?.

Drawing on the background earlier, this article attempts to analyse and advocate for local community's perspective on environmental threats and its relation to the government's security policy. In doing so, the article uses a case study method to explore how the local community in Sukamaju Village, whose residents are particularly vulnerable to the threats noted above, perceives the nuisance they experience. In this article, we first discuss the theoretical framework as well as methodology in detail. Then next, we try to describe the results of the interviews with several local community sources about human security issues and the dilemmas they were experiencing. Finally, we explain the relationship between the local community perspective and the existing security policy by using an actor-based security model.

\section{Material and Methods}

\subsection{Environmental Degradation, Human Security, and Actor-based Security Approach: A Theoretical Framework}

Some literatures assert that the emergence of human security as a people-centred rather than state-centred approach to human development began with the issuance of the UNDP's HDR in 1993 and 1994 [2,16,21]. This report is often considered to have changed the mainstream security paradigm after the Cold War, which initially focused on military power and inter-state conflict as the key to global peace. As discussed in the introduction, in 2005, through the UN Secretary-General's report, the concept of human security was based on three main pillars: 'freedom from want and fear, and the freedom to live in dignity'([2], p. 15). The main idea of the human security is that people have the right to life, dignity, freedom from poverty, and equal opportunity to develop their potentials. In other words, this perspective is mainly spawned by the cosmopolitan notion of a universal humanity providing a framework to decide who is vulnerable (in terms of security) and must be protected [17]. In the study of International Relations, human security occupied the realm of the normative theory that discusses how the world should be managed and what choices should be made by decision makers. In contrast to the realism approach, which explains why countries compete with each other in an anarchic system, human security assesses whether behaviour is morally acceptable and how it affects individuals and society [16]. 
Therefore, unlike the traditional security paradigm where the referent object is the state, the focus of human security is the individual, groups of individuals and communities. People encounter threats and danger from various directions - to health, access to food and water, or the environment-which are no longer solely from the weapons of foreign military forces. Hence, human security is not just a concern for the state but involves many actors, including NGOs, business people, religious organisations, and various civil society movements. Human security can be achieved if there is collaboration from various parties to achieve a comprehensive security condition, which releases people and society from all fears and needs [17].

In relation to the issue of environmental degradation, human security also raises the matter of the emergence of potential threats and dangers to people from the environment [22] A special concern over environmental damage as a threat to security emerged after the Cold War. Homer-Dixon (1991, cited in [23]) states that environmental damage can lead to conflict, especially in poor countries, through four factors: 1) reduced agricultural production; 2) economic decline; 3) forced displacement of population; and 4) disruption of social relations. However, as stated by [2], while human security has actually brought attention to environmental security as one of its important elements since 1993, in its development, environmental security has become more independent and emergent from its roots in human security. In fact, according to Elliott, the study of environmental security is better understood by using the orthodox security paradigm that focuses on the state as a referent object.

More operationally, in analysing the concept of human security to environmental policy in Citarum, this research uses the actor-based security model developed by [20].

In this case, it starts with a vulnerable local community affected by environmental degradation as a key actor in security policy. As seen in Figure 1, this model gives voice to that community's fears and concerns, and allows its experience to be taken into consideration in policy setting, which aligns with Elliott's notion of the importance of attending and integrating the local community as a fundamental requirement of human security [21]. Security is a process of moving toward a secure feeling, by identifying the cause of the fear and finding ways to overcome it. It opens the discussion on the vulnerability and insecurity experienced by local populations. It has two objectives: first, to reveal the source of their insecurity, and then to discuss how to regain their security [20].

Security can be achieved if individuals or actors have the freedom to identify factors that threaten what they perceive as valuable. They want freedom for opportunities to convey the threats to other actors, and the ability to mitigate those threats. Society is one of the actors, together with industry and NGOs, the media, the military, government officials and researchers. Thus, threats that are perceived (and expressed) by local actors can be synchronised with threats identified by researchers. Other actors also con- vey their perspectives on security and threats in particular contexts, which can then be used as a basis for seeking compromises or solutions [20].

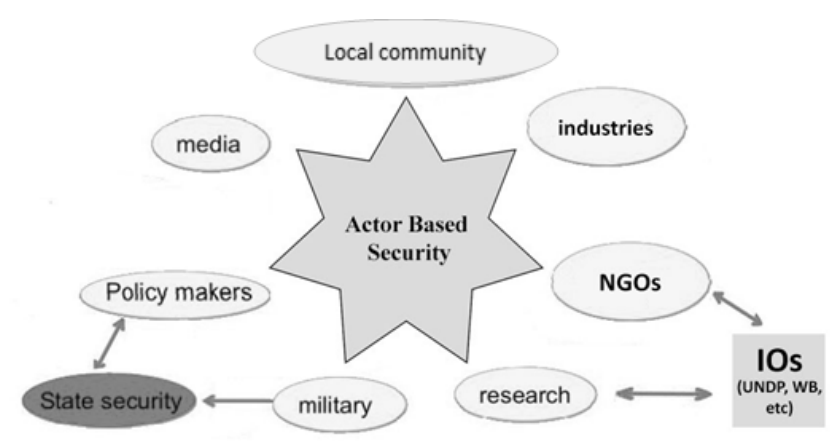

Figure 1. Actor-based security model adapted from [20].

\subsection{Study Area}

The Citarum River plays a very influential role in the life of West Javan people. It flows through 12 administrative regencies and cities and supplies water for some 28 million people, including in the Greater Bandung Area, Jakarta (the capital city of Indonesia), Bekasi, Karawang, and Purwakarta. It stretches for $269 \mathrm{~km}$ with its watershed area of $6080 \mathrm{~km}^{2}$, which passes through three dams, one of which is the Jatiluhur Dam, with a capacity of three billion cubic metres, and an agricultural irrigation area of 240,000 hectares. It also provides roughly $80 \%$ of the water needs for Jakarta's population [24].

The Citarum River Basin is commonly used by the surrounding communities, which leads to a conflict of interests between groups fighting over water resources. According to [25], there are at least three contested interests in the Citarum River Basin for the use of water resources: the domestic sector, including agriculture; the urban sector; and industry. This is confirmed by [6], who assert that the causes of environmental damage to the river regions are the shifting functions from forest land to urban and industrial lands. A study conducted by [4] examines Land Use and Land Cover Change (LULCC) in the upper Citarum River Basin from 1997 to 2014. It describes how agriculture was the dominant use covering nearly $65 \%$ of the upper Citarum River Basin, followed by $15 \%$ developed area, $10 \%$ forests, and $10 \%$ other uses. There has been a significant change in land use over the last two decades with burgeoning agriculture expansion and urban sprawl, and drastically decreasing forest area [4]. In the context of land use change, it is more due to drastic population growth and massive economic development in the area of the Greater Bandung Area, which is the main area of the upper river basin [4]. This land use change has been the biggest contributor to large scale deforestation and environmental pollution in the Citarum River Basin.

Given this severe environmental degradation, the management of the Citarum River Basin has not been managed according to the appropriate regulations. Data from the 
Environmental Service of West Java Provincial Government states that there are at least 1,900 industries along the Citarum River Basin, $90 \%$ of which do not have an adequate waste water management installation. Nonetheless, they produce some 340,000 tonnes of liquid waste per day [26]. The river is also polluted by agricultural activities and domestic waste from neighbouring communities, including pesticides to household waste $[11,14]$.

The current research focuses on security concerns of the local community affected by pollution from the river. It took place in Sukamaju Village, Bandung Regency, West Java Province. As pictured in Figure 2, this location was chosen as the focus of the case study due to its position on the river basin, where the water is used by three parties: residents (domestic consumption), farmers and the textile industry. For daily needs, the people use dirty river water. The condition of Sukamaju has been attracting researchers' attention from universities and NGOs, including local and international media. Some clean water procurement programmes have been conducted in the village, although they are still temporary. When we conducted the field research in July-November 2018, the people of Sukamaju were still using polluted water for personal sanitation.

\subsection{Methods}

The field research was carried out from March to November 2018. It used a qualitative approach and a case study method which focused on qualitative data such as interpretation of the findings gathered from the informants. Case study was chosen as the method for data collection, which is comprehensive and deep for ambitious cases seen as relevant and compelling [27]. By using this method, the research contexts of space, time and theme are key.

As described earlier, we chose Sukamaju Village, Bandung Regency, West Java Province, Indonesia as a research location. The village is relevant and compatible with the theoretical framework, in which there are at least three contested interests in the struggle for water resources-domestic sector, urban sector and industry [25]. All three are represented in the village and its district, Ma- jalaya, which also plays a role as a buffer for Bandung City, through which the river flows. Like many industrial areas which intersect with agricultural areas, its position is on the urban-rural border. As such, it represents the inter-actor complexities in the region. The most important objective in choosing Sukamaju Village as a research locale was that it is situated in Sector 4 of the Citarum River Basin, which is the first sector along the basin affected by environmental pollution from industrial waste.

Interviews were conducted with sources using the snowball method, in which subsequent sources are determined from the findings during the study. The interviews were done in two stages. The first was to meet the sources from several active stakeholders, including the Environmental Agency of West Java Provincial Government and some NGOs, such as Wahana Lingkungan Hidup or Walhi (Life Environment Commission) of West Java and Elemen Lingkungan or Elingan (Environmental Element). Using open-ended questions, the interviews were allowed to develop along with discussions and findings in the field. Secondly, the interviews were conducted either one-on-one or by group discussion with people from Sukamaju Village. Twenty people were interviewed, of whom 17 of them are listed in Table 1 below.

In analysing the data, the research passed through several stages: 1) labelling and memo writing; 2) theme-based categorisation of the threat(s) experienced by people and their responses; and 3) interpretation of findings [27]. As a first step, we conducted the labelling and writing process of the data collected from the interviewees. This process was carried out inductively on the entire data set so that it could be seen which data were relevant and which were not. We then categorised the data that had been labelled based on a thematic study derived from a theoretical framework. This data categorisation was done so that the structure of the overall data could be known and validated with triangulation techniques. Finally, from the theme-based categorisation, we interpreted the data with the help of a theoretical framework as a heuristic device for analysing and summarising the research findings. 


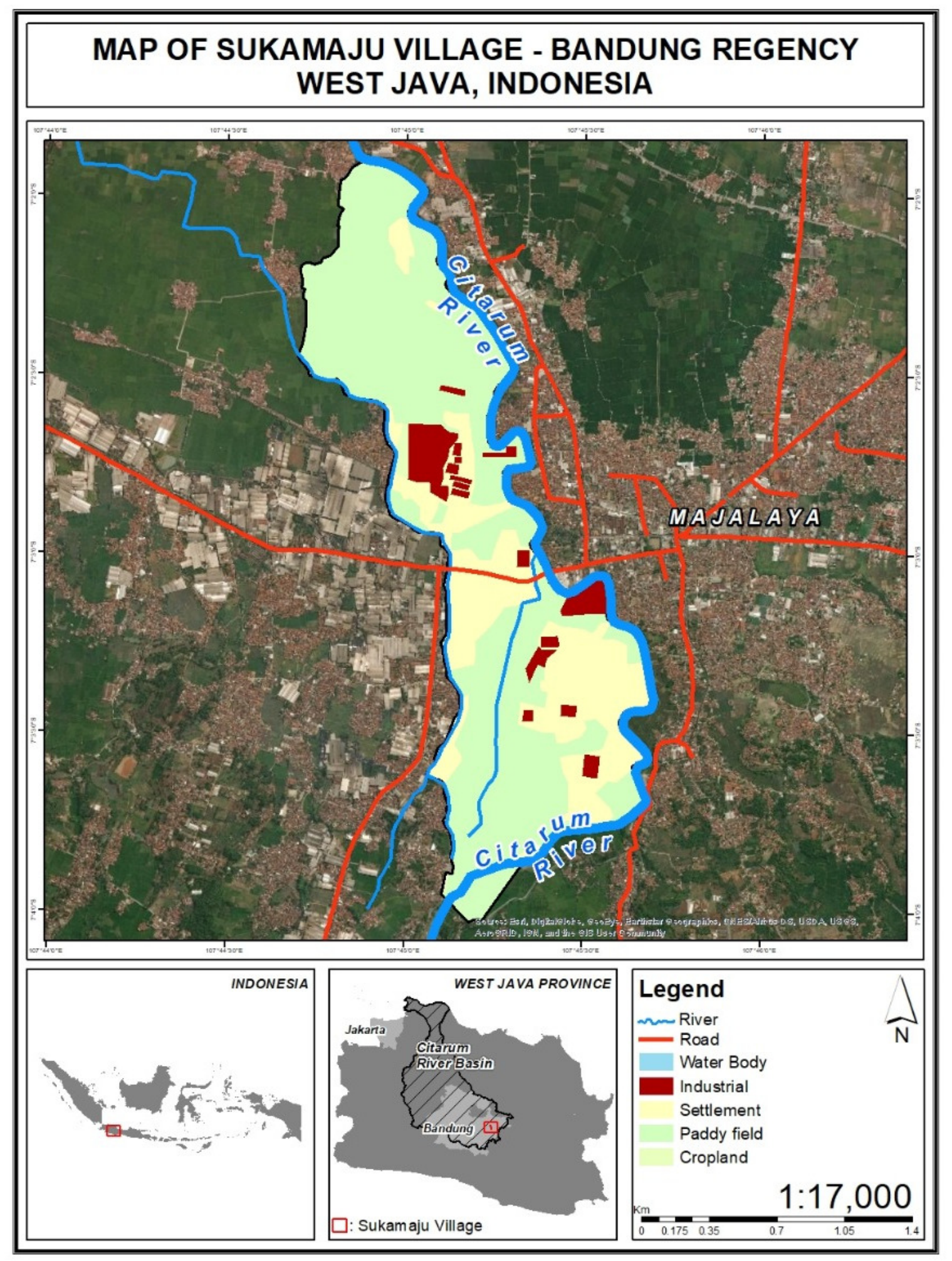

Figure 2. The map of Sukamaju Village, Bandung Regency, West Java, Indonesia. 
Table 1. List of informants.

\begin{tabular}{|c|c|c|}
\hline No. & $\begin{array}{l}\text { Name } \\
\text { (ficti- } \\
\text { tious) }\end{array}$ & Details \\
\hline 1 & Asih & $\begin{array}{l}\text { Sells fried banana; her husband works } \\
\text { freelance }\end{array}$ \\
\hline 2 & Wina & $\begin{array}{l}\text { Wife of Head of Neighbourhood; her husband } \\
\text { works as security in textile industry }\end{array}$ \\
\hline 3 & Isah & Sells ready-to-eat foods; a widow \\
\hline 4 & Ati & $\begin{array}{l}\text { Wife of Head of Neighbourhood; her husband } \\
\text { works in textile industry }\end{array}$ \\
\hline 5 & Wati & Wife of Head of Neighbourhood; NGO activist \\
\hline 6 & Eni & $\begin{array}{l}\text { Wife of Head of Neighbourhood; used to work } \\
\text { in textile industry }\end{array}$ \\
\hline 7 & Kat & $\begin{array}{l}\text { An elderly person who was affected by } \\
\text { environmental pollution in Sukamaju }\end{array}$ \\
\hline 8 & Uma & Former Head of Neighbourhood \\
\hline 9 & Ana & Spouse who work as people's cemetery officer \\
\hline 10 & Tar & Public figure in Sukamaju \\
\hline 11 & Usu & Farmer \\
\hline 12 & Amo & $\begin{array}{l}\text { An elderly person who lives in Citarum River } \\
\text { Basin }\end{array}$ \\
\hline 13 & Lily & A resident who live in Citarum River Basin \\
\hline 14 & Adi & $\begin{array}{l}\text { Water Resources Processing Officer of Citarum } \\
\text { River Basin Area, Majalaya District }\end{array}$ \\
\hline 15 & Ren & $\begin{array}{l}\text { NGO activist who advocates for the Sukamaju } \\
\text { people }\end{array}$ \\
\hline 16 & Ned & $\begin{array}{l}\text { NGO activist who advocates for the Sukamaju } \\
\text { people }\end{array}$ \\
\hline 17 & Andi & State official \\
\hline
\end{tabular}

\section{Results}

\subsection{Perception of Sukamaju Village Residents about Security}

Since research of [18] several years ago, the negative effects of pollution in Sukamaju Village still remain in various dimensions. In the health sector, for example, people near the river, especially those close to industrial areas, often experience health problems due to the industrial waste and pollution. In the agriculture sector, productivity of rice production centres in West Java, such as the Rancaekek District, have dropped dramatically. The poor condition of the river has been ongoing for decades, but the local and central governments have not managed to overcome it. This has led to dissatisfaction with government in the affected societies.

This section will show our exploration how local people perceive the security threats they experience. The general question posed to them was how they felt about the dirty water conditions, skin diseases, smells, floods and coal dust from factories around the village. Regarding the concept of security, almost all interviewees were confused when asked, 'Do you feel threatened by this condition?' or 'Do you feel safe?' When the questions were rephrased with the words 'fear' or 'anxiety', they immediately understood and were able to express their feelings of insecurity. From the submitted answers, a number of threats, fears and anxieties sources could be identified.

\subsubsection{Lack of clean water}

Almost all interviewees stated that it is difficult to find clean water due to waste pollution by the textile factories along the river. This has been the case in Sukamaju over the last decade, especially in Bale Kambang and Leuwi Dulang area, since the textile factories laid claim to this portion of the river basin along Sector 4 . The change of land functions from agriculture to industry without good environmental management has damaged the availability of clean water for residents. This massive transfer of land functions into industrial land is more driven by foreign investors who compete with local textile industries.

According to Kat, interviewee 7, an elderly citizen in Sukamaju, the biggest issue faced by the Sukamaju residents is the scarcity of clean water not only during the dry season, but throughout the year. Residents are unable to access clean water provided by Perusahaan Daerah Air Minum or PDAM (Regional Water State-Owned Enterprise) because of the limitation of the catchment area and the costs, which they find expensive. PDAM water is only enjoyed by a few people who live near the main road in the Majalaya District.

To fulfil their sanitation needs, the residents depend on river water contaminated with industrial waste. As Kat said: 'If the river water is contaminated with red waste, the water we get is also red. If the waste is yellow, the water will turn yellow'. Kat said that the colours come from fabric dyes in textile factories which are dumped directly into the river. Another source, Ana, interviewee 9, said: 'For cooking purposes we prefer to buy bottled or refilled water, while for bathing or washing we inevitably use Citarum water'. Water pollution also affects the quality of public wells in various places in Sukamaju. According to Kat: 'The polluted water seeps and affects groundwater, including the public wells. There used to be a well that could be considered to be the cleanest, but now it has been polluted by river water seepage, and that water is also dirty'.

As observed during the field research, the water used by residents for washing, bathing, and cooking contained dirt particles and was not clear. Residents kept the dirty water in a bucket for several days until the particles settled and then used it for cooking.

Based on the findings, the scarcity of ground water in Sukamaju is caused by several factors. First, textile factories around Sector 4 of the river basin directly dump their industrial waste into the river without processing it first. This has a detrimental effect on the quality and acidity of the water. The infiltration of ground water has also affected residents' wells in Sukamaju. Secondly, the textile factories also control Citarum's water resources in the upper reaches 
of Sector 4, where the Radug Water Gate managed by the Bandung Regency Government is located. According to several interviewees, water canals for residents were often co-opted by the industries, including water canals for agricultural irrigation purposes. Third, the textile factories also use artesian wells to extract ground water for production purposes, thereby disrupting the ground water availability for residents' wells, most of which are shallow: 'So this factory extracts water from the ground, draws water from the river, and there are many artesian wells that violate the regulated quota limits. So of course we have ground water scarcity for the residents' (Tar, interviewee 10; Usu, interviewee 11).

\subsubsection{Skin disease}

The use of river water for bathing and daily needs results in various health problems. A number of interviewees, particularly women, claimed to feel anxious every time they showered because the water was dirty: 'Yes, I'm afraid, but I just pray. After all, what can I do?' (Eni, interviewee 6). One of the interviewees said that they had gotten used to health threats due to polluted water because there was no other choice: 'Well, what can I do? It's been so common' (Kat, interviewee 7).

$\mathrm{He}$ added that the most vulnerable groups of the polluted water are children because they do not have good immunity. 'Most children like to play in the water or on the river, and usually they will suffer from skin diseases. So we generally use BPJS [Badan Penyelenggara Jaminan Sosial; National Body for Social Insurance] to treat children's skin diseases' (Kat, interviewee 7).

There was an expression of 'pity' that arises from one of the woman interviewees when her child was sick. Asih, interviewee 1, felt sorry for her child who suffers from skin diseases. She also complained that if her child was sick, she would have to take him to the Public Health Centre, and it meant she had to spend extra money; as much as 12,000 IDR (slightly less than USD\$1) for public transport and medicine. Her husband is unemployed (he occasionally gets work as an agricultural labourer) while she sells fried bananas for a profit of 10-25,000 IDR (approximately USD \$1\$2) per day. At the Public Health Centre, she was scolded by the medical staff: 'You already know that the water is dirty, why still use it to take a bath [but] what else can we do? This is the only water we can use' (Asih, interviewee 1).

She uses river water for bathing and washing, while for cooking, she holds river water in a bucket for several days until the mud and dirt settles. For drinking, she buys bottled mineral water. She admitted that sometimes she is anxious with the water conditions: 'But I have already got used to it, what can I do after all?' (Asih, interviewee 1).

\subsubsection{Air pollution containing coal dust}

As a result of the implementation of new policies for energy savings in industry, textile factories along Sector 4 have used coal as the fuel for their boilers instead of using petrol.
Many interviewees stated that every time they hang their clothes out, there were black dust stains on them from coal dust. Isah, interviewee 3 , claimed to have bronchitis due to the dirty air. It worried her that it will make her sick again. Her husband, who worked in the factory, died from a respiratory illness. Ati, interviewee 4, expressed her worries about the condition of her two-year-old son who had begun to develop respiratory diseases: 'Back then, children rarely suffered from respiratory illness. Now it is common that young children has already has respiratory pain'. Similarly, Lily, interviewee 13, claimed that her child suffered from asthma because every day she was exposed to coal-fired air pollution from a factory directly opposite her house.

Ana explained that textile factories around Sukamaju dispose of their smoke waste daily. For them, 'it is so common that there is coal dust on the roof and on the banana leaves'. Uma, interviewee 8, also complained of the same thing: 'Coal smoke floats off depending on how the wind blows. If the wind goes to the residents' areas, the smell makes me dizzy. In the rainy season, the dust will become smelly mud and make it itchy'. Besides the children, according to Tar, interviewee 10, air pollution is also dangerous for the elderly.

\subsubsection{Negative impact on residents' economy}

As a result of the pollution of water in Sector 4 of the river basin, especially in recent decades, the fisheries in Majalaya District have closed. There is no market demand because buyers generally know that water in Majalaya has been polluted by industrial waste: 'we have tried to grow fish, but they cannot grow. Instead they grow to be deformed,' said Usu, interviewee 11. One elderly person who lives on the banks of the river, Amo, interviewee 12, also gave the same information: 'We have tried to grow fish, it has not been five months to die'.

Environmental pollution in Citarum Sector 4 has ended fish farming, especially in Sukamaju and Majalaya, two villages along the basin. Environmental pollution also affects agriculture in Sukamaju, especially in the Bale Kambang area. A community leader, Tar (Interviewee 10), said: 'Irrigation is dry in dry season, Citarum also becomes dry, agriculture in Sukamaju is hampered. Even if it grows, it grows, but there are no seeds'.

This has encouraged agricultural involution in Sukamaju, where there is a decline in the function of agricultural land and the number of people who work as farmers. One of the interviewees who is a farmer, Usu (Interviewee 11), said: 'Agricultural production has dropped dramatically. Even in the harvest season there are only five rice stalks. The leaves are dry and seedless. So 20,000 IDR [\$1.50] a day for $1,400 \mathrm{~m}^{2}$ [of rice fields]. It used to be seven quintals of rice, now only a bag'.

Depreciation has occurred in almost all agricultural land in the past decade due to the conversion of land to industrial complexes. This is worsened by the theft from irrigation canals at the Radug Water Gate by the industries that have made special hoses for their production needs. 


\subsubsection{The threat of floods due to silting}

Apart from the fear and anxiety mentioned above, some residents of Sukamaju and other villages along the river such as Majalaya village expressed a sense of dread of flash floods during the rainy season. In the past few years, Majalaya District has often been hit by flash floods resulting in huge losses. As Lily, interviewee 13, one of the respondents who had been a victim of the floods, said, 'This disaster was caused by the rise of river sediment due to environmental destruction upstream which caused silting of the rivers, coupled with bad habits of the surrounding communities who littered'. Amo, interviewee 12, who lives right on the edge of the river, also complained of fear when entering the rainy season: 'In the rainy season, water levels can soak homes around the banks of the river'.

\subsection{Survival: Compromising with the Environmental Threats to Maintain Economic Security}

The fear and anxiety of Sukamaju residents described above is an insecurity expression caused by environmental threats in the river. Although most residents lack security awareness, the way they see and perceive the conditions and problems shows that these environmental threats have become a source of fear and anxiety in their lives. However, further findings in this study indicate that this fear and anxiety comes not only from environmental threats, but also from the dynamics that arise in the relationship between the economic structures of citizens and industry.

When the female interviewees are asked if they tried to protest against the factory, some answered that it was men's business. When asked who was responsible for polluting the river water, Wina, interviewee 2, replied, 'I don't know. A lot of fear'. Some of interviewees stated that they had participated in a strike protesting against the factory, but their protests were not heard. Apart from people's aspirations that were not heard by industry players, people also feared being fired. Many people in the village did not want to take part in the protest because they were afraid of being fired from the factory. This was confirmed by another interviewees who stated that she and her husband did not want to join the protest because they needed money from the factory even though she said that inside the factory the air was suffocating due to the use of coal.

Almost $80 \%$ of Sukamaju residents depend on textile factories for their livelihoods. This economic structure relationship increases people's fears that were originally only environmental threats to include an economic threat. Many people remain silent and compromise with polluted water conditions and unhealthy environments as long as they still get money from the textile factories to survive: 'For example, when Citarum Harum programme which involves Siliwangi Regional Indonesian Military Command was launched, disciplinary actions were carried out by closing illegal sewage holes in factories. However, as a result there were lots of layoffs in a large number, many of which are Sukamaju residents. This clearly creates a dilemma for the residents'
(Kat, interviewee 7).

The residents do not dare protest because the village officials would immediately report to the factory and the participants would be threatened with being fired, although nowadays courage has recently arisen among residents as assistance from several NGO activists has emerged. However, their advocacy efforts often clash with industry-paid people or security guards. There is potential for horizontal conflict between residents intentionally carried out by the industry players. According to one of the interviewees from a local NGO, there is often intimidation from mass organisations, factory thugs, security guards.

In terms of human security, intimidation can be seen as another form of threat to humans in the case of industrial structure relations in Sukamaju. Intimidating methods by the factory towards the control of water resources can also be seen at the Radug Water Gate located in the upstream area in Sector 4 of the river basin. Based on the findings in this research, there are several potential horizontal conflicts where residents from Sukamaju are desperate and try to seize water resources from the factory: 'Only a few years ago, there were residents who brought hoes and machetes to request for water' (Usu, interviewee 11).

Due to the very high level of vulnerability in the struggle for water resources, many residents prefer to be silent and compromise with the situation as the only way to survive. According to the interviews, there was once government aid for clean water provision but, due to the limited water debit, conflict emerged between residents. This conflict led to an unsafe circumstances and residents felt threatened. Finally, the clean water supply was stopped because there was no assistance and supervision from the related agencies.

We tried to triangulate the data to the official narrative regarding the affected society. The government acknowledges that its programme to develop eco-villages (villages that are healthy and safeguard the environment) can only reach a small part of the affected societies and that Sukamaju had not been touched. The programme to build an eco-village was carried out by recruiting 25 residents in a village. They were trained in the concept of environmental protection and waste management. Ideally, the surrounding villagers independently replicate and develop this concept in their respective areas. However, village officials do not have that eagerness and instead wait apathetically for the central government to arrive with the eco-village program ready-made. Village funds distributed by the central government are used for physical infrastructure projects that are not environmentally based, such as road construction and buildings not clean water installations and waste management.

In March 2018, the central government launched the Citarum Harum programme involving Indonesian military personnel to restore the condition of the river by issuing Presidential Regulation Number 15 Year 2018 [28] about acceleration of Citarum restoration. According to interviewees, the army monitors the factories and prevents them from dumping chemical waste into the river, but factories 
always find ways so that coloured waste (which is strongly suspected to contain hazardous chemicals) is still dumped in the river when there is no supervision. The temporary presence of the army also prevents residents from throwing household waste into the river and gets them to work voluntarily cleaning the river. Since there is no waste processing installation, while the waste continues to be produced, it goes nowhere else but to the river.

\section{Discussion: Neglected Local Vulnerabilities and Incapability of the State in Overcoming the Threat}

The findings in this research indicate that the Sukamaju residents understand and are aware of the security threats from environmental pollution in the river. The fear and anxiety experienced by almost all interviewees, on topics such as the scarcity of clean water and potential disease, indicate that the residents are in a threatened condition. However, their awareness of environmental threats is not followed by their ability to articulate their fears and anxieties to other security actors, especially the government. Although there has been a lot of research and advocacy effort from various NGOs and universities, the residents of Sukamaju still have no means to influence policy.

Their inability to convey what they feel to other actors ultimately causes them to be unable to mitigate the threats. This inability arises due to dilemmatic condition, where the source of fear is not only environmental, but also economic. Because they are economically dependent on the textile factories, most residents choose to keep quiet and compromise with the environmental threats. As a result, environmental threats are ultimately no longer perceived as a source of insecurity that needs to be anticipated. Instead, they tend to consider them as ordinary environmental hazards, such as skin disease or respiratory disease. Along with the exclusion from the security policy and the inability of residents to articulate their insecurity, the findings show that the residents tend to choose to survive and compromise with the threats rather than advocate their aspiration to policy makers.

The increasingly massive and well-established industrial economic structure in the Sukamaju area has created two sources of latent fear and anxiety for citizens: environmental and economic threats in the form of dependence and intimidation. Residents are forced to hold back their fear over environmental threats to overcome economic threats due to industrialisation that are not environmentally based. Unfortunately, this threat is missed by the state as a policy maker, both at the central and local level.

Meanwhile, the government's policy in managing environmental issues in Citarum River is generally overlapping. At present, there is a synergistic and integrated management by Tim Koordinasi Pengelolaan Sumber Daya Air or TKPSDA (the Coordination Team of Water Resources Management) of the river region under a decree from the Minister of Public Works and Public Housing. In the field, there is the army involvement coordinated by the Governor of West
Java Province. TKPSDA integrates programmes that have been prepared by both the local and central governments, but the army focuses more on physical movements, such as community service and waste management. The army has greater freedom in matters of waste. If a factory is found to dispose of coloured waste, the army immediately closes its water drain. As a result, industrial operations are hampered, and the factory lays off employees.

According to the findings, physical projects carried out by the army, such as a river waste-cleaning programme, did not resolve the problem because it was primarily a waste pick-up method that did not address the human security issues suffered by the people who are directly affected by environmental pollution. Based on this regulation, the Citarum Harum programme also lacked a human security concern, as it did not regulate or give the authorities the incentives to restore and rectify the community's quality of life that had been grossly affected by the severe pollution. This state-centred policy relies on bureaucracy and even military personnel. It tends to perceive the community as part of the environmental degradation problem, rather than as the victims. Accordingly, the government tends to dictate the threat indications to the people rather than involving them, to identify the threats they have been experiencing.

Various programmes run by the government in last several decades always stop in the middle of the road. For example, in 2001 the Citarum Bergetar programme was launched. It sought to install $1,800 \mathrm{MW}$ of electricity generation to meet the electricity needs in Java Island and Bali Island. In 2014 the Citarum Bestari aimed to make the river water drinkable by 2018. After previous failed attempts in managing the environmental issues, in 2018, a new programme called Citarum Harum was started, which involved a role for the Indonesian Army. These programmes were mainly financed by debt funds from the international community, such as the World Bank and ADB $[18,19]$ Despite a large financial investment, however, they could not synchronise all the stakeholders. For example, some interviewees said that the pollution source upstream is generally liquid waste from chemical fertilisers used by farmers. This should be directed to generate organic fertilisers and encourage farmers to switch to ecological agriculture, but the Ministry of Agriculture, which has authority in this matter, continues to supply chemical fertiliser to the farmers from one of the state-owned enterprises.

Strictly speaking, throughout the journey of managing environmental issues in the Citarum River, there is no good communication relationship between actors in the security policy which results in the state as a policy maker is not functioning properly. The government does not seem to pay proper attention to human security issues in the river despite of many researches from universities and political pressure of local NGO's. The breakdown of articulation about the fear experienced by residents in Citarum River Basin area, especially in the Sector 4, made the country carelessly execute many failed environmental pollution prevention programmes. From the perspective of human security, the government 
does not seem to realise and understand the importance of citizens' freedom from fear of existential threats caused by environmental pollution. Instead, the local community perceives that the state is no longer a source of security, as said by Ren, interviewee 15 and a local NGO activist: 'The government and its elites still treat it [the environmental issues in Citarum] as an economic and political commodity'.

\section{Conclusions}

This research shows that there is a very complicated human security issue in the case of environmental degradation in the Citarum River Basin. Findings on local community perceptions show that there are sources of fear and existential threats due to environmental pollution. However, they should compromise with the threats as a form of resilience to survive and maintain their economic security, which is their economic dependence on textile factories in the area. The dilemma leads these residents to ignore and compromise with environmental threats as a form of resilience mechanism, such that they prefer to keep quiet rather than articulate what they feel to other actors. This dilemma and the inability of local people to advocate for themselves based on their experience, profoundly contributes to the ignorance of environmental policy made by the government.

As the result, based on the actor-based security model, the tendency to silence and build a survival mechanism has marginalised local people from the security policy making process. There is an articulation channel that stagnates from residents affected due to their internal factors

\section{References and Notes}

[1] Fox CA, Sneddon C. Transboundary River Basin Agreements in the Mekong and Zambezi Basins: Enhancing Environmental Security or Securitizing the Environment? International Environmental Agreements: Politics, Law and Economics. 2007;7:237-261. doi:10.1007/s10784-007-9036-4.

[2] Elliott L. Human Security / Environmental Security. Contemporary Politics. 2015;21:11-24. doi:10.1080/13569775.2014.993905.

[3] Grumbine R. Using Transboundary Environmental Security to Manage the Mekong River: China and South-East Asian Countries. International Journal of Water Resources Development. 2017;34:1-20. doi:10.1080/07900627.2017.1348938.

[4] Agaton M, Setiawan Y, Effendi H. Land Use/Land Cover Change Detection in an Urban Watershed: A Case Study of Upper Citarum Watershed, West Java Province, Indonesia. Procedia Environmental Sciences. 2016;33:654-660. doi:10.1016/j.proenv.2016.03.120.

[5] Chen W. Environmental Externalities of Urban River Pollution and Restoration: A Hedonic Analysis in Guangzhou (China). Landscape and Urban Planning. 2017;157:170-179. doi:10.1016/j.landurbplan.2016.06.010.

[6] Adi Kuntoro A, Putro A, Kusuma MSB, Natasaputra S. The Effect of Land Use Change to Maximum and Minimum Discharge in Cikapundung River Basin. vol. 1903; 2017. pp. 100011. 10.1063/1.5011621.

[7] Indonesia's Most Poluted River. Aljazeera. 2018; Available from: https://www.aljazeera.com/programmes/101east/2018/05/ indonesia-polluted-river-180502051143231.html.

[8] Indonesia's Citarum: The World's Most Polluted River. The Diplomat. 2018; Available from: https://thediplomat.com/2018/04/indonesiascitarum-the-worlds-most-polluted-river/. and external pressure. This study has tried to raise what is felt and perceived by the local community so that the most affected of them can be considered by the policy makers, both the government and other stakeholders. The government's perspective that only looks at the prevention of river pollution is a solely state-centred policy that does not resolve the real threat source for residents of Sukamaju. This finding of the article supports previous research conducted by [2] that, decades after its emergence, the idea of human security has had little impact on environmental issues, specifically in how people's freedom from fear and want and also freedom to live in dignity are implemented in practice and policy level.

In the context of Citarum River, we suggest that the Indonesian government needs to consider the perceptions and the conditions of local community, who are vulnerable, in security policy making process. Studies related to human security, thus, need to be developed to influence the security policy in overcoming environmental threats, especially in affected communities with marginal positions. Further research is needed to analyse the complexity of the implementation of human security on environmental issues.

\section{Acknowledgments}

The authors thank the Directorate of Research, Community Service, and Innovation (DRPMI) of Universitas Padjadjaran which has funded the research. The authors also thank the anonymous reviewers, editors, and informants for their valuable contributions.
[9] Citarum, the Most Polluted River in the World? The Telegraph. 2014; Available from: https://www.telegraph.co.uk/news/earth/environment/ 10761077/Citarum-the-most-polluted-river-in-the-world.html.

[10] The World's Dirtiest River. Unreported World. 2017; Available from: https://www.youtube.com/watch?v=AkSXB-IRAp0.

[11] Laporan Terbaru: Sungai Citarum Mengandung Bahan Kimia Berbahaya. [Citarum River Contains Dangerous Chemical Substance]. Mongabay. 2012; Available from: https://www.mongabay.co.id/2012/11/29/laporan-terbaru-sungaicitarum-mengandung-bahan-kimia-berbahaya/.

[12] Bukit T. Water Quality Conservation for the Citarum River in West Java. Water Science and Technology. 1995;31(9):1-10. doi:10.1016/0273-1223(95)00400-H.

[13] Logam Berat di Air Citarum Merusak Susunan Saraf [Heavy Metal in Citarum Water Damaging The Nervous System] The Indonesian Ministry of Health; 2018. Available from: http://www.depkes.go.id/article/view/18041000001/logam-berat-diair-citarum-merusak-susunan-saraf.html.

[14] Djuangsih N. Understanding the State of River Basin Management from an Environmental Toxicology Perspective: An Example from Water Pollution at Citarum River Basin, West Java, Indonesia. Science of The Total Environment. 1993;134:283-292. doi:10.1016/S00489697(05)80029-4.

[15] Hermawan P, Kijima K. Conflict Analysis of Citarum River Basin Pollution in Indonesia: A Drama-theoretic Model. Journal of Systems Science and Systems Engineering. 2009;18:16-37. doi:10.1007/s11518009-5096-z.

[16] Koff H, Maganda C. Environmental Security in Transnational Contexts: What Relevance for Regional Human Security Regimes? Globalizations. 2016;13(6):653-663. 
doi:10.1080/14747731.2015.1133043.

[17] Martin M, Owen T, editors. Routledge Handbook of Peacebuilding. Routledge Handbooks Online; 2014. doi:10.4324/9780203068175.

[18] Cavelle J. A Political Ecology of the Citarum River Basin: Exploring "Integrated Water Resources Management" in West Java, Indonesia. Globalizations. 2016;13(6):653-663. doi:10.1080/14747731.2015.1133043.

[19] Fulazzaky MA. Challenges of Integrated Water Resources Management in Indonesia. Water. 2014;6:2000-2020. doi:10.3390/w6072000.

[20] Hoogensen Gjørv G, Bazely D, Christensen J, Tanentzap A, Bojko E. Human Security in the Arctic-Yes, It Is Relevant! Journal of Human Security. 2009;5:1-10. doi:10.3316/JHS0502001.

[21] Morrissey J. Towards a Human Security Vision of Global Climate Action. Geoforum. 2019;pp. 220-222. doi:10.1016/j.geoforum.2019.08.010.

[22] Mason M, Zeitoun M. Questioning environmental security. The Geographical Journal. 2013;179(4):294-297. doi:10.1111/geoj.12030.

[23] Chalecki EL. Historical and Current Overview of the Issues. In: Environmental Security: A Guide to the Issues; 2013. pp. 1-25.

[24] Lubis R, Delinom R, Martosuparno S, Bakti H. Water-Food Nexus in Citarum Watershed, Indonesia. IOP Conference Series: Earth and Environmental Science. 2018;pp. 012023. doi:10.1088/17551315/118/1/012023.

[25] Hengsdijk H, van der Krogt WNM, Verhaeghe RJ, Bindraban PS. Consequences of supply and demand management options for integrated water resources management in the Jabotabek-Citarum region, Indonesia. International Journal of River Basin Management. 2006;4(4):283-290. doi:10.1080/15715124.2006.9635297.

[26] 'Ini Alasan Citarum Sempat Masuk Daftar Sungai Terkotor di Dunia' (These Are The Reasons Why Citarum River Gets in The List of The Dirtiest River in The World). Available from: https://news.detik.com/berita/d-3957166/ini-alasan-citarumsempat-masuk-daftar-sungai-terkotor-di-dunia.

[27] Djamba YK, Neuman WL. Social Research Methods: Qualitative and Quantitative Approaches. Teaching Sociology. 2002;30(3):380. doi:10.2307/3211488.

[28] Presidential Regulation Number 15 Year 2018 about the Acceleration of Controlling on Environmental Degradation and Citarum River Basin Damage. Available from: https://peraturan.bpk.go.id/Home/Details/ 73584/perpres-no-15-tahun-2018. 